http://dx.doi.org/10.12775/szhf.2015.056

RAFA£ MichaLSKI

Uniwersytet MikoŁaja Kopernika, Toruń

METABASIS1@WP.PL

\title{
Rozważania wokół platońskiej koncepcji śmiechu
}

\author{
Wprowadzenie
}

Platon porusza zagadnienie śmiechu zaledwie w kilku fragmentach swoich dialogów. Dygresyjne uwagi na ten temat pojawiają się w Protagorasie i Gorgiaszu, więcej wskazówek zawiera natomiast Teajtet, w którym filozof przytacza słynną anegdotę o upadku Talesa do studni. Analiza tej anegdoty obejmująca szerszy kontekst kulturowy (odniesienia do Starego Testamentu) będzie stanowić przedmiot rozważań pierwszego paragrafu niniejszego artykułu zatytułowanego Smiech trackiej służacej. Drugi paragraf stanowiący jego główną część omawia już bezpośrednio koncepcję śmiechu, którą filozof wykłada w Państwie i w Filebie. Platon poświęca zagadnieniu śmiechu najwięcej miejsca w trzeciej księdze Państwa, gdzie poddaje krytyce zgubne oddziaływanie komedii na stan duszy jej odbiorców. Komizm apeluje, jego zdaniem, do niższych emocji, wytrąca ludzki umysł z równowagi i podważa panujący porządek wartości. Destrukcyjny wpływ śmiechu ilustruje filozof ustępami z Iliady i Odysei. Szczegółowe omówienie przykładów homeryckiego asbestos gelos (nieugaszonego śmiechu) pozwoli nam lepiej uchwycić sedno platońskiej koncepcji. Swoją negatywną ocenę komizmu Platon uzasadnia 
bardziej szczegółowo w Filebie w ramach dyskusji na temat natury przyjemności i przykrości. Śmiech kojarzy tutaj z doznaniem zawiści - jak tłumaczy greckie phtonos Władysław Witwicki.

Analiza wskazanych fragmentów doprowadzi nas do konkluzji, że Platon pojmuje śmiech nader jednostronnie jako namiętność zrodzoną z poczucia wyższości nad innymi ludźmi. Śmiech staje się w jego ujęciu przedłużeniem władzy i dominacji, a w ostatecznym rozrachunku zawsze prowadzi do upokorzenia swojego adresata. Jednostronność platońskiej koncepcji stanie się wyraźna, gdy porównamy ją z literacką figurą „śmiechu Demokryta”, który pełni funkcję terapeutyczną i katarktyczną. Śmiech stanowi tutaj wyrazisty sygnał, który zapoczątkowuje krytyczną refleksję nad sobą samym i daje impuls do zmiany postawy wobec świata. Platon nie uwzględnia w swoich pismach takiego dydaktyczno-poznawczego znaczenia śmiechu, dlatego staje się on $\mathrm{w}$ jego filozofii swoistym antagonistą prawdziwego poznania. To zaś rodzi pewien kłopotliwy paradoks $\mathrm{w}$ jego stanowisku filozoficznym. Negatywna postawa wobec śmiechu nie wspólgra bowiem z uznaniem, jakim Platon darzy Sokratesa, który wykorzystywał ironię jako kluczowy element swojej metody dochodzenia do prawdy.

Niniejszy artykuł pomyślany jest jako swoiste wprowadzenie do drugiego przygotowanego do publikacji tekstu ${ }^{1}$, który będzie traktował o ironii sokratejskiej widzianej przez pryzmat Chmur Arystofanesa. Obydwa artykuły tworzą tematyczną ciągłość, wzajemnie nawiązują do siebie i uzupełniają się. Nicią przewodnią zawartych w nich rozważań jest problematyka śmiechu i jego znaczenie dla filozofii. Platon - twórca dialogów przesyconych różnymi rodzajami komizmu, który paradoksalnie potępia komedię, Sokrates - naczelny filozof ironista i wreszcie Arystofanes - klasyk greckiej komedii - wszyscy trzej poważnie traktują kwestię śmiechu, chociaż przypisują mu różne funkcje i znaczenia. Analiza porównawcza dokonana w obydwu artykułach ma na celu wydobycie punktów wspólnych i różnic kryjących się wizjach śmiechu, jakie przedstawiają w swoich utworach trzej koryfeusze greckiej kultury, a być może pozwoli ona nam również, przynajmniej częściowo, zrewidować spojrzenie na filozofię Sokratesa i Platona.

Zanim przejdziemy do właściwych wywodów, podejmiemy, tytułem wprowadzenia, ogólną refleksję o naturze śmiechu, unikając jednak zamykania tego fenomenu w sztywnych definicyjnych granicach i w klasyfikacyjnych ty-

${ }^{1}$ R. Michalski, Czy prawda boi się śmiechu? Platon i Arystofanes wobec sokratejskiej ironii (rękopis). 
pologiach. Dla jasności argumentacji przyjmiemy jedynie roboczo dwie podstawowe formy śmiechu: poznawczo-katarktyczną i destruktywno-karzącą. Pierwsza otwiera perpektywę prawdy, oczyszczając poznanie z przesądów, błędów myślowych i konceptualnego pomieszania, druga zaś służy jako środek wywierania fizycznej lub symbolicznej przemocy na osobach „słabszych”, odstających od normy społecznej czy po prostu nie mieszczących się w granicach panującego status quo. Pierwsza apeluje zatem do rozumu, druga - do splątanych emocji.

Obserwując niejako z lotu ptaka dzieje myśli filozoficznej, można odnieść wrażenie, że filozofię przenika nastrój ociężałej melancholii, filozof to ktoś, kto wprawdzie daje się ponieść dziecięcemu zdziwieniu, ale w swoich dociekaniach, wątpliwościach pozostaje nieumiarkowanie poważny. Nieustępliwość w zadawaniu pytań, surowa dyscyplina narzucona myśleniu i jakiś równie obsesyjny, co niekonkluzywny upór w drążeniu tematu wytrącają filozofa z kolein codziennego doświadczenia, a niekiedy całkowicie wykluczają go z kręgu swojskiej codzienności. Pozycja zdystansowanego obserwatora życia, umysłu i kosmosu mimowolnie prowadzi do usztywnienia filozofującego podmiotu (najsłynniejszą egzemplifikacją jest tutaj przypadek „oniemiałego od myślenia" Sokratesa, który potrafił całymi godzinami stać bez ruchu). Od znieruchomienia „oblekającego życie” pozostaje zaś już tylko mały krok do komizmu, jeśli chcielibyśmy przywołać definicję Henri Bergsona². Pochłonięty badaniem rzeczy na ogół niepojętych filozof chcąc nie chcąc zamienia się w myślącą marionetkę 3 , ulega niegroźnej nerwicy natręctw, która każe mu kompulsywnie wracać do tych samych wątków, słowem - dziwaczeje. Hamowane emocje - warunek sine qua non abstrakcyjnego myślenia - co jakiś czas wybuchają w nim w postaci groteskowych idiosynkrazji - widownia ogląda wówczas komiczny monodram z poruszaną „niewidzialną ręką afektu” kukiełką w roli głównej. Ale przecież jest to jak najbardziej powszechna, ludzka przywara. Filozofowanie stanowi tylko jej szczególny przypadek. Filozofia naraża się na śmieszność podobnie jak każda inna profesja, chociaż przyznać trzeba, że zawarty w niej potencjał groteskowości jest nadzwyczaj duży. W swoim dążeniu do wypowiedzenia niewyrażalnego doskonale wpisuje się ona bowiem w kantowską definicję dowcipu - w istocie często nie jest niczym innym, aniżeli napiętym oczekiwaniem, które nagle obraca się w niwecz ${ }^{4}$. Nie

\footnotetext{
${ }^{2}$ H. Bergson, Śmiech, tłum. S. Cichowicz, Kraków 1977.

3 Tamże, s. 116 i nn.

${ }^{4}$ I. Kant, Krytyka władzy sądzenia, tłum. J. Gałecki, Warszawa 1986, s. 271.
} 
tyle jednak intensywność i heroiczny niemal patos, z jakim uprawia się filozoficzne dociekania, lecz przede wszystkim ich mizerny, jeśli nie zgoła żaden rezultat, przywodzi nieuchronnie na myśl bezgranicznie rozwlekły i pozbawiony puenty dowcip. W tej perspektywie znaczna część historii filozofii to jakby dzieje przydługich, źle opowiedzianych dowcipów, których funkcjonalny sens sprowadza się do tego, że rozładowują intelektualne napięcie i zużywają nadmiar psycho-witalnej energii ich twórców i ewentualnie - cierpliwych odbiorców.

Jeśli zgodzimy się na taki punkt widzenia, to będziemy musieli również przyznać, że filozofię dręczy wstydliwa dialektyka powagi i śmieszności, ciągłe oscylowanie między postawą kapłana-mizantropa i cynicznego błazna. $\mathrm{W}$ niniejszym artykule nie chcemy jednak podejmować psychologicznych dociekań o śmiechu filozofów, o ich zamierzonym lub nie komizmie, choć z pewnością znaleźlibyśmy tutaj bogaty materiał do biograficznych gabinetów osobliwości. Za Helmuthem Plessnerem przyjmujemy, że śmiech stanowi graniczny fenomen ludzkiej natury lub, wyrażając się ostrożniej - tym razem za Hannah Arendt - ludzkiej kondycji ${ }^{5}$. Śmiech jako graniczna reakcja jest symptomem utraty kontroli nad psycho-fizyczną jednością, ale zarazem potwierdzeniem naszej wolności - w momencie, gdy brakuje nam słów, gdy kapitulujemy jako racjonalne istoty, śmiech, choć na wskroś cielesny, odsyła nas na drodze okrężnej do porządku symbolicznego. Śmieje się bowiem tylko ten, kto rozumie jakiś ustrukturyzowany porządek - słów, rzeczy, zachowań. Graniczność tego doświadczenia odsłania, z jednej strony, drzemiącą w nas zwierzęcość, a z drugiej - zdolność do dystansowania się wobec siebie i wobec świata. Śmiech uprzytamnia nam, że nie jesteśmy w stanie zapanować bez reszty nad rzeczywistością przyrodniczą, społeczną czy kulturową, ani też nad nami samymi.

Plessner dowodzi, że śmiech można wprawdzie opisać jako rodzaj ekspresji, ale w istocie nie wyraża on żadnych emocji. Chcielibyśmy w tym miejscu skorygować koncepcję niemieckiego antropologa, odwołując się do intuicji zawartej już w starożytnych wyobrażeniach mitologicznych. Dobrego przykładu dostarcza nam w tym kontekście kultura Sparty, gdzie czczono boga śmiechu Gelosa (gr. gelos) obok boga lęku (phobos) i śmierci (thanatos) ${ }^{6}$.

${ }^{5}$ H. Plessner, Śmiech i płacz, tłum. A. Zwolińska, Z. Nerczuk, Kęty 2004; H. Arendt, Kondycja ludzka, tłum. A. Łagodzka, Warszawa 2000.

${ }^{6}$ Boga Gelosa wspomina Filostrat Starszy w swoim opisie obrazu Andryjczyków w: Filostrat Starszy, Obrazy, tłum. R. Popowski, Warszawa 2004, s. 169. Więcej na ten temat: L. Prütting, Homo ridens, t. 1, München 2013, s. 163-164. 
Zapewne nigdy nie dowiemy się, jakie przyczyny legły u podłoża takiej konstelacji boskich epifanii. Jednak zestawienie to nasuwa przypuszczenie, że mamy tutaj do czynienia z jakimś głębokim powiązaniem trzech kluczowych dla ludzkiej kondycji stanów emocjonalnych. Namacalny związek śmiechu z lękiem, a zwłaszcza z lękiem przed śmiercią znajdziemy w obfitej literaturze opisującej reakcje żołnierzy na froncie czy, w ogólności, reakcje ludzi, którym udało się umknąć przed śmiertelnym zagrożeniem - śmiech działa tutaj jak środek katarktyczny, rozładowuje napięcie, przywraca równowagę. Czy możemy rozszerzyć tę obserwację na inne rodzaje śmiechu? Czy każdy rodzaj śmiechu jest podszyty jakąś rudymentarną postacią lęku i w paradoksalny sposób zapowiada nieuchronne doświadczenie śmierci?

Jeśli poważnie potraktujemy obraz świata i ludzi przedstawiony w komicznej deformacji, będziemy musieli przyznać, że ukazuje on w istocie rzeczywistość w stanie rozpadu: ludzkie uniwersum tuż przed nadchodzącą katastrofą. Korowód szaleńców, ludzi opętanych chroniczną głupotą, złośliwe teściowie, niewierni mężowie, skorumpowani politycy, parodystyczna degradacja uznanych wartości, prymitywny, patologiczny erotyzm, skatologia, zbrodnie, urzeczowienie - wielorakie stabuizowane bądź całkowicie wyparte z oficjalnego porządku pokłady treści tworzą nieskończenie zmienny, kalejdoskopowy obraz świata, który utracił stałe fundamenty i nieuchronne zmierza do agonalnego chaosu. Śmiech rozbrzmiewa w tej perspektywie jak sygnał alarmowy, jak ostrzeżenie przed końcem świata, jaki znamy. Co najgorsze sam śmiech może stać się narzędziem zniszczenia. Ta właśnie obawa skłoniła Platona do wyeliminowania komedii z projektu idealnego państwa. Śmiech degraduje i upokarza zarówno wynaturzenia ludzkiej natury: nikczemność, głupotę, małostkowość etc. - taką funkcję gelos Platon mógłby jeszcze zaakceptować, jak i to, co szlachetne, wartościowe. Irracjonalność śmiechu, jego neutralność względem dobra i zła stanowi poważne zagrożenie dla ustroju, w którym ma rządzić rozum oświetlony blaskiem prawdziwego poznania.

\section{1. Śmiech trackiej służącej}

W starożytnej Sparcie bóg śmiechu występował w dionizyjskim orszaku tuż obok boga zabawy i festynów - Komosa ucieleśniającego chaos, anarchię i nieokiełznany eksces. Grecy dobrze wiedzieli, że śmiech jako witalna siła kryje w sobie destrukcyjny potencjał - nawet w swoich pozytywnych wariantach, kiedy uwalnia od zahamowań, rozładowuje napięcie i jednoczy, nadal pozostaje narzędziem przemożnej destrudo. Ta ambiwalentna niszczą- 
co-wskrzeszająca funkcja śmiechu była wykorzystywana w rytualnych, czysto obrzędowych zachowaniach, potem doszła do głosu w teatrze Dionizosa w okresie tak zwanej komedii starej (V w. p.n.e.). Deifikacja gelos unaocznia jego graniczny charakter i numinotyczną moc. Śmiech działa obezwładniająco, nie tylko wytrąca nas z psychofizycznej równowagi, ale poniekąd wyrzuca na zewnątrz, jest swoistą ekstazą, wykroczeniem poza obszar kontrolowany przez świadomość. Śmiech to również graniczny punkt komunikacji, który pojawia się tam, gdzie zawodzą argumenty, gdzie myśl załamuje się na skale milczenia i niemocy, zatwardziałej oporności głupoty i niewiedzy. W jego czysto akustycznym przejawie dochodzi do głosu osobliwa eksplozja języka. Kiedy mowa milknie, nie znajduje właściwych słów, które mogłyby stanowić adekwatną odpowiedź na komiczną sytuację, pojawia się niepohamowany wybuch śmiechu, tak jak gdyby nagle eksplodowało uniwersum mowy, jak gdyby strumień uporządkowanych sylab, morfemów a wraz z nim wszystkie syntaktyczne powiązania i podziały, przekształciły się nagle w artykulacyjny chaos. Niemota śmiechu, jego irracjonalność i niepodatność na poznanie spowodowała, że filozofia poświęcała mu niewiele uwagi.

A jednak jako, zdawałoby się, całkowicie peryferyjny fenomen śmiech zawsze towarzyszył zmaganiom filozofów z pułapkami, jakie zastawiało na nich życiowe doświadczenie. Niemal od samego początku, jeśli zawierzymy historycznej anegdocie, filozofia ocierała się o śmieszność. W dialogu Teajtet Sokrates przytacza Teodorowi, zaprzyjaźnionemu geometrze z Kyreny, słynną historię o Talesie, który badając gwiazdy, wpadł do studni, czym wywołał śmiech trackiej służącej. Na pierwszy rzut oka mogłoby się wydawać, że Sokrates wykorzystuje ten przykład, aby ośmieszyć, choć z wyraźną nutą sympatii, jałowość teoretycznej hybris, która traci z oczu codzienne życie, jego konflikty, pragnienia i potrzeby. Być może taką postawę przyjąłby rzeczywisty Sokrates, ale z pewnością nie platoński. W dialogu z Teodorem chodzi mu bowiem o coś innego: porównuje mianowicie dwie przeciwstawne drogi życia: filozofa i nie-filozofa, drogi wolności i zniewolenia. Zwróćmy uwagę, że figurę nie-filozofa reprezentuje tutaj prawnik, a zatem autentyczny polites, który aktywnie angażuje się w życie polis, uczestniczy w ecclesia, rozsądza bieżące spory, a zatem ktoś, którego życie uchodziło podówczas za ucieleśnienie wolności. Ta kontrintuicyjna, niska ocena statusu nie-filozofa ze strony platońskiego Sokratesa stanowi oczywiście symptom kryzysu Ateńskiej demokracji, zwiastuje rozpad pewnego ideału życia, który był tak bliski ówczesnym Grekom. Oderwany od życia filozof wydaje się pozostałym mieszkań- 
com miasta głupcem i nieudacznikiem. Coś jest na rzeczy w tej opinii, gdyż jak stwierdza sam Sokrates:

Taki się naprawdę ludźmi nie interesuje, o najbliższym sąsiedzie nie tylko nie wie tego, co on robi, ale bez mała tego nawet nie wie, czy to człowiek, czy też jakie inne stworzenie. A tylko co to właściwie jest człowiek i jakie natura ludzka posiada zdolności czynne i bierne w odróżnieniu od innych natur ${ }^{7}$.

Umysł zaprzątnięty kwestiami ostatecznymi sam skazuje się na porażkę w codziennej krzątaninie, w sądzie, w prozaicznych konfliktach, które nigdy nie opuszczają wąskiego kręgu prywatnych interesów. Chcąc nie chcąc pada ofiarą szyderstwa i kpiny. W ten obraz oderwanego od życia filozofa doskonale wpisuje się Sokrates, chociaż wiemy, że z dużym zapałem angażował się w tworzenie demokracji ateńskiej, sprawował funkcję sędziego, walczył jako hoplita i znał jak własną kieszeń palące bolączki Ateńczyków. Mimo oznak życiowej przytomności jego charakterystyczny wygląd i zachowanie, osobliwy habitus życiowy musiał ściągać na niego drwiny ze strony mieszkańców stołecznej polis. Ale również w swoich obsesyjnych dociekaniach docierał nieraz do granicy śmieszności. Przywołajmy tylko fragment z Protagorasa, kiedy pod koniec dyskusji na temat tego, czy można nauczyć się cnoty, na które to pytanie obydwaj rozmówcy ostatecznie odpowiadają tak samo, chociaż wychodzą z innych założeń - puentą debaty okazuje się być rozbrajający śmiech. „Ten koniec naszej rozmowy wygląda mi jak człowiek, który nam zarzuty robi i obśmiewa nas, a gdyby miał głos ludzki, powiedziałby: Dziwni wy jesteście, Sokratesie i Protagorasie" ${ }^{8}$. Sokrates choć był niewątpliwie zaangażowany w sprawy publiczne Aten, często popełniał gafy i ściągał na siebie szyderczy śmiech. Przykład znajdziemy w dialogu Gorgiasz, gdzie filozof dzieli się z Polosem następującym wspomnieniem: „Ot, zeszłego roku los na mnie padł do Wielkiej Rady; kiedy służba przyszła na moją grupę i mnie wypadało zarządzić głosowanie, ośmieszyłem się i nie umiałem zarządzić głosowania"9. Oczywiście w oczach Platona te słabostki w żaden sposób nie umniejszają wielkości jego nauczyciela. Świadczą raczej o małostkowości i ograniczeniu ateńskiego tłumu. Śmiech ludzi skutych łańcuchami konieczności życiowych, zamkniętych w kołowrocie animalnego bios, działa jak mechanizm obronny: odrzuca na zewnątrz wszystko to, co podważa sens poziomych poruszeń niższej części duszy na rzecz werty-

\footnotetext{
7 Platon, Teajtet, [w:] Platon, Dialogi, t. 2, tłum. W. Witwicki, Kęty 2005, s. 377 (174 B).

${ }^{8}$ Platon, Protagoras, [w:] Platon, Dialogi, t. 1, tłum. W. Witwicki, Kęty 1999, s. 330 (361 A).

9 Platon, Gorgiasz, [w:] Platon, Dialogi, t. 1, tłum. W. Witwicki, Kęty 1999, s. 379 (473 E).
} 
kalnych obrotów psyche, które wznoszą się ku rzeczom ostatecznym. W Teajtecie Platon wyraźnie nawiązuje do fragmentu Państwa, gdzie oświetlony blaskiem idei filozof powraca do jaskini i odzwyczajony od panującego tam półmroku potyka się, wywołując gromki śmiech tamtejszych mieszkańców. $\mathrm{W}$ tym kontekście omawiana przez nas dygresja z Teajteta działa jak rodzaj riposty, a właściwie odwetu na nikczemnie drwiącej z umiłowania mądrości gawiedzi. Dowiadujemy się bowiem, że kąśliwy śmiech może w pewnych sytuacjach zmienić swojego adresata:

A jeśli on kogoś, przyjacielu, do góry podciągnie i zechce się ktoś dla niego wznieść ponad takie zagadnienia jak: czy to ja ciebie w czymś krzywdzę, czy ty mnie, do rozważania sprawiedliwości samej i niesprawiedliwości [...] o tym wszystkim, kiedy mówić będzie musiał tamten człowiek o małej duszy, tamten pieniacz chytry i zacięty, wtedy on dla odmiany da widowisko takie, jak tamten dawał poprzednio. Głowa mu się kręcić zacznie, tak wysoko się znajdzie $\mathrm{w}$ przestworzu zawieszony, tak bardzo mu z góry patrzeć wypadnie - nieprzyzwyczajonemu; bardzo będzie smutny i zakłopotany i pleść zacznie byle co, na śmiech nie dziewczętom trackim ani komukolwiek z ludzi niewykształconych - ci tego nie zauważą - śmiać się z niego będą wszyscy wychowani tak, jak wolnym ludziom przystało ${ }^{10}$.

Siła rażenia śmiechu $\mathrm{z}$ „wyżyn” zdaje się być znacznie większa niż moc „oddolnej” kpiny, ponieważ dotyka sedna ludzkiego życia, jego celu i istoty.

Śmiech, na który wskazuje tutaj Platon wybucha z podobnych powodów, co skodyfikowany literacko przez Pseudo-Hipokratesa śmiech Demokryta ${ }^{11}$. Otóż czytamy tam, że mieszkańcy Abdery zaniepokojeni niecodziennym zachowaniem Demokryta, który nieustannie śmieje się z ludzi, z ich kłopotów, pragnień i dążeń, posądzają go o szaleństwo i wzywają Hippokratesa na pomoc. Proponują również dość groteskową etiologię manii filozofa - jej źródłem ma być nadmiar mądrości. A zatem śmiech i nadmiar mądrości to dwa główne czynniki determinujące odchylenie od normy. W oczach swoich krajan Demokryt jawi się jako karykatura cynika, który bezlitośnie drwi z wszelkich wartości wspierających codzienne działania zwykłych ludzi. Przedawkowanie mądrości wywołuje swoiste zaburzenie humoralne, melancholijny śmiech człowieka oderwanego od życia. Oczywiście po rozmowie z Demokrytem Hippokrates zmienia zdanie i stwierdza, że śmiech płynący z „nadmiaru wiedzy” celnie wytyka szaleństwo samych Abderytów, uwi-

\footnotetext{
${ }^{10}$ Platon, Teajtet..., s. 378-379 (175 C-D).

${ }^{11}$ Pseudo-Hippokrates, O śmiechu Demokryta, tłum. K. Bartol, Gdańsk 2007.
} 
kłanych w pogoń za płonnymi pragnieniami. Brak spokoju ducha, nieznajomość ludzkiej natury, a przede wszystkim niezrozumienie podstawowej prawdy, że świat jest zmienny, a wszystko nieuchronnie przemija, powoduje zaślepienie polites goniących za sławą, bogactwem, przyjemnością i władzą. „Śmiech z filozoficznych wyżyn” staje się tutaj specyficznym środkiem dydaktycznym, wyrazistym sygnałem, który ma zapoczątkować refleksję nad sobą samym i dać impuls do zmiany postawy wobec świata. Zachowanie Demokryta jest zatem nie tylko narzędziem wyrażania przekonań, ale i próbą realizowania moralnej misji filozofa. Tak jak Hippokrates trudzi się o przywrócenie zdrowia ludzkiego organizmu, tak atomista próbuje uleczyć chorobę ludzkiej duszy.

Różnica między Platonem a Demokrytem w odniesieniu do gelos sprowadza się do różnicy w rozumieniu jego funkcji. Filozof z Abdery wierzy w jego moc terapeutyczną, a wręcz katarktyczną, chociaż zarazem zdaje sobie sprawę z jego małej skuteczności, natomiast Platon całkowicie odrzuca tego rodzaju nadzieje - śmiech staje się w jego filozofii swoistym antagonistą prawdziwego poznania i w tym właśnie odbiega od roli, jaką odgrywa w komediowej poetyce Arystofanesa. Platońska psyches omma (oko duszy) dąży bowiem ostatecznie do transcendencji, do wyjścia ze świata zmysłowych pozorów, a oglądając w wizyjnym uniesieniu noetyczny kosmos, nieruchomieje i milknie - byt prawdziwie bytujący nie daje bowiem żadnych powodów do śmiechu.

A jednak przywołując historię o Talesie, Platon pozwala w pewnym sensie, niejako na drodze okrężnej, śmiać się z samego siebie. Być może jest w tym coś $\mathrm{z}$ autoironii, ale mimo to cienia wątpliwości nie pozostawia negatywna ocena „śmiechu z wyżyn”. Wyżyny to tymczasowa pozycja dominacji, to intensyfikacja ślepej energii witalności, która pozwala szydzić nawet z tego, co jest $\mathrm{z}$ natury szlachetne. Śmiejąca się tracka dziewczyna - uosobienie beztroski młodości, życiowego common sense wspólnoty - wydaje się niewinna w porównaniu z sadystycznym tłumem i reprezentującym go sądem, który skazuje Sokratesa na śmierć. Platon wyraźnie czuje, że niewinna drwina łatwo może przekształcić się $\mathrm{w}$ tanatyczny cios, dlatego do końca pozostaje wstrzemięźliwy, jeśli nie krytyczny wobec irracjonalnego gelos. Pamiętajmy, że Teajtet został napisany po śmierci Sokratesa. Dla Platona zderzenie dwóch różnych ujęć rzeczywistości, różnych dyskursów, jakbyśmy dziś powiedzieli, kryje w sobie jak w zarodku groźbę katastrofy. Nie łagodzi bynajmniej tej oceny pogodna zgoda Sokratesa na cykutę. Śmiech jawi się tutaj jako sygnał 
alarmowy, ostrzegawcze wezwanie do rozwagi, dlatego Platon nie chce śmiechu w swoim idealnym państwie.

Śmieszność Sokratesa, jak i każdego filozofa staje się zatem nieuchronną częścią jego losu, ceną, jaką musi zapłacić za odejście od panującego status quo. „Kiedy mu w sądzie albo gdzieś indziej wypadnie mówić o tym, co tuż pod nogami albo przed nosem, na śmiech się naraża - nie tylko u dziewcząt trackich, ale i u jakiego bądź innego tłumu, kiedy w różne studnie i wszelkiego rodzaju kłopoty wpada, bo doświadczenia nie ma"12. Sokrates przedstawiony w Teajtecie wydaje się rozdarty między „patrzącym wokół siebie” Sokratesem z wczesnych dialogów, który zrozumiał, że filozofię należy sprowadzić z nieba na ziemię, a Sokratesem „czysto platońskim”, który ponownie wznosi wzrok ku niebu - tym razem jednak nie ku niebu astronomów, lecz ku niewidzialnemu kosmos noetos. Dialog pokazuje, że cnota rozumiana jako wiedza jest możliwa i w pełni uzasadniona dzięki nadzmysłowym ideom. Pytanie o fundamenty, o to, co pierwsze siłą rzeczy odwraca wzrok od świata empirycznego. Myśl o tym, żeby filozofia na powrót zamieszkała w zwykłych domach, wśród ludzi, okazuje się więc naiwnym marzeniem. Ironiczny dialog, dialektyczne łamigłówki to wprawdzie ważne, ale w istocie jedynie wstępne wprawki do prawdziwej episteme. Z perspektywy późnego Platona niewątpliwie zacny i godny pochwały koncept uprawiania filozofii, który ucieleśniał w swoim życiu Sokrates, nosi znamiona tragikomizmu. Sam Platon nie wypowiada się nigdzie wprost na ten temat, ale, jak pokazaliśmy, w kilku miejscach ukazuje aurę śmieszności, jaka otaczała jego nauczyciela. Mimo wyraźnej sympatii nie broni jednak zdecydowanie ani Talesa, ani Sokratesa, wskazuje tylko na ułomność śmiechu, który płynie z niewiedzy i braku opanowania. Inaczej postępuje Arystoteles, przynajmniej w odniesieniu do Talesa. W Polityce legitymizuje mianowicie teoretyczne pasje Jończyka, wskazując przykłady praktycznych zastosowań jego filozofii. Arystoteles tworzy tam coś w rodzaju anty-anegdoty do epizodu z tracką służącą. Otóż kiedy wytykano Talesowi jego ubóstwo i bezużyteczność filozofii, ten opierając się na obserwacjach astronomicznych przewidział, że niebawem skończy się susza, zakupił więc za bezcen tłocznie oliwek i z dużym zyskiem sprzedał je w czasie urodzaju. W ten sposób udowodnił - jak utrzymuje Arystoteles „[...] że dla filozofów łatwą jest rzeczą zgromadzenie bogactwa, jeśli tylko ze-

${ }^{12}$ Platon, Teajtet..., s. 377 (174 C). 
chcą, tylko, że nie jest to celem, do którego ich wysiłki zmierzają." ${ }^{13}$ Arystoteles dostarcza zatem kontrargumentu skierowanego przeciwko pustej retoryce „śmiechu z filozofa”. Praktyczne zastosowanie wiedzy legitymizuje bezinteresowne i bezużyteczne $\mathrm{w}$ oczach gawiedzi pragnienie poznania, a ponadto, w pewnym sensie, usprawiedliwia również uszczypliwy śmiech dziewczyny, która nie mogła przecież nic wiedzieć o pożytkach płynących z umiłowania mądrości. Tyle Arystoteles.

Wracając do Platona warto mieć na uwadze to, że anegdotę o Talesie przejął on od Ezopa i zmodyfikował na tyle, że zyskała ona intrygującą wieloznaczność. Jak pokazuje Blumenberg jej pierwotna wersja znajduje się w korpusie ezopowych bajek, tyle, że nie ma tam ani postaci Talesa ani trackiej służącej. Zacytujmy za Blumenbergiem wersję Ezopową:

Pewien astronom miał zwyczaj oglądać gwiazdy w czasie wieczornych wycieczek. A gdy pewnego wieczoru spacerował po przedmieściach i z całą uwagą wpatrywał się w niebo, wpadł niespodziewanie do studni. Do studni podszedł przechodzeń, który usłyszał skargi i nawoływania i gdy dowiedział się, co się stało, powiedział do astronoma: a to ty mi się udałeś! Próbujesz wyśledzić rzeczy na niebie, a nie widzisz rzeczy na ziemi ${ }^{14}$.

Jak zauważa Blumenberg morał tej anegdoty dotyczy człowieka, który próbuje egoistycznie wynieść się ponad innych, a sam nie jest w stanie urzeczywistnić tego, co wspólne wszystkim ludziom. To jakby rozrachunek z dawną arystokracją, która za czasów Ezopa zaczęła odchodzić w zapomnienie. Daleko stąd zatem do opozycji theoria - doxa, którą uwypukla wersja platońska. $\mathrm{W}$ zmodyfikowanej i wzbogaconej o kontekst sokratejski wersji anegdoty z Teajteta trudno znaleźć jednoznaczny morał. Być może sam Sokrates czuł ukryte powinowactwo $\mathrm{z}$ mądrym niewolnikiem Ezopem, gdy wspominał go w celi na dzień przed własną śmiercią, co pokazuje Platon w Fedonie. W rozmowie z przyjaciółmi Sokrates przyznaje, że zaczyna odczuwać przyjemność $\mathrm{z}$ powodu przebywania $\mathrm{w}$ więzieniu, mało tego, po raz pierwszy w życiu zaczął pisać wiersze i poetyzowane przeróbki bajek Ezopa, a uczynił tak, gdyż miał widzenie senne, w którym usłyszał wezwanie do zajęcia się muzą poezji.

\footnotetext{
${ }^{13}$ Arystoteles, Polityka, [w:] tenże, Dzieła wszystkie, t. 6, tłum. L. Piotrowicz, Warszawa 2001, s. 40 (1259 a).

${ }^{14}$ H. Blumenberg, Der Sturz des Protophilosophen - Zur Komik der reinen Theorie anhand einer Rezeptionsgeschichte der Thales-Anekdote, [w:] Das Komische, (wyd. W. Presendanz, R. Warning), München 1976, s. 17.
} 
A po bogu zważywszy, że poeta, jeżeli ma być poetą, powinien przypowieści pisać, a nie myśli choćby i sam był bajarzem, więc dlatego mając pod ręką i umiejąc na pamięć bajki Ezopa, ułożyłem je wierszami ${ }^{15}$.

Pamiętajmy, że mówi to filozof na dzień przed swoim straceniem, a z racji tego, że dialog, w którym wypowiada swoje słowa, jest swoistym epitafium na jego cześć, możemy przyjąć, że Platon mimo idealizacji próbuje oddać jakiś aspekt jego prawdziwej osoby. Czyżby zatem Sokrates dokonał tutaj drugiego egzystencjalno-poznawczego zwrotu? Jeśli pierwszy pozwolił mu uwolnić się od hylozoizmu, to czy drugi oznaczałby porzucenie własnej dialogicznej filozofii? Taką tezę stawia Blumenberg w artykule, który omawia recepcję anegdoty o Talesie w całej późniejszej filozofii:

Następca proto-filozofa Talesa w ostatniej fazie swojej twórczości jeszcze raz odwraca się od kontemplacji nieba, ale ponadto od jej negacji w filozofii ludzkich domostw i zajmuje pozycję przechodzącej, drwiącej dziewczyny ${ }^{16}$.

Utożsamienie postawy filozofa ironisty z reakcją trackiej dziewczyny wydaje się w tym kontekście trafne. W Fedonie rzeczywiście wyczuwa się nutę zwątpienia w głosie Sokratesa, kiedy wspomina on, że przez całe życie, sądził, iż filozofia była dla niego największą służbą Muzom, ale na koniec sam Apollo zmusił go do pisania poezji. Niezależnie od tego, jak zinterpretujemy postać oczekującego na własną śmierć filozofa, to znaczy jako „Sokratesa prawdziwego” czy też jako „Sokratesa platońskiego” jego zwątpienie dotyczy skuteczności dyskursywnego poznania w osiąganiu prawdy. Ostatecznie triumfuje tutaj Platon, który w późnej fazie twórczości już wie, że prawda odsłania się tam, gdzie zawodzi pojęciowy język i dlatego coraz częściej sięga do narracji mitologicznej i myślenia analogicznego.

W kwestii śmiechu Sokrates ironista wydaje się stać znaczniej bliżej Demokryta niż Platona. W niniejszym artykule spróbujemy potwierdzić, jeśli nie słuszność, to przynajmniej prawdopodobieństwo tego przypuszczenia, zestawiając koncepcję śmiechu Platona z wizją śmiechu, jaką przedstawia w Chmurach Arystofanes Wspólnym, choć stale umykającym punktem odniesienia będzie tutaj postać Sokratesa, którą autor Państwa wprzęga w tryby własnej filozofii idei, a ateński komediopisarz kontaminuje z figurą sofisty i filozofa przyrody. W obydwu przypadkach, niejako w jednoczesnym ruchu odsłonięcia i zakrycia, wyłania się cień rzeczywistej postaci słynnego ironisty. Świadomie piszę tutaj o cieniu, gdyż z góry rezygnuję z dyskusji na temat

\footnotetext{
${ }^{15}$ Platon, Fedon, [w:] Platon, Dialogi, t. 1, tłum. W. Witwicki, Kęty 1999, s. 631 (61 B).

${ }^{16}$ H. Blumenberg, Der Sturz..., s. 18.
} 
tego, która wersja Sokratesa jest bliższa prawdy. Sokrates widziany z różnych perspektyw w każdej z nich uosabia specyficzne podejście do gelos - pozostaje nam tylko szczegółowo przyjrzeć się owej różnicy. Zanim to zrobimy, wróćmy po raz ostatni do anegdoty o Talesie.

Gdybyśmy uznali, że ukazuje ona mit założycielski filozofii, to obraz ten nie byłby zbyt pokrzepiający dla jej adeptów. Pod pewnymi względami przypomina on mityczną narrację o innej archetypowej postaci - [,] a mianowicie o starotestamentowym, kulejącym Jakubie. W kontekście śmiechu znamienne jest już imię jego ojca Izaak, które dosłownie oznacza „tego, który chce się śmiać" ${ }^{17}$. Życie Izaaka jak na gorzką ironię losu nie obfitowało jednak w zabawne epizody, z Biblii dowiadujemy się głównie o nieprzerwanym paśmie nieszczęść i cierpień, które go nawiedzały. Jego syn Jakub również nie był uosobieniem bohatera komicznego, ale bez wątpienia przez stosunkowo długi czas musiał borykać się ze wzgardliwym śmiechem współplemieńców, przynajmniej do momentu, kiedy stoczył heroiczny pojedynek z tajemniczym Aniołem.

Zarówno Tales, jak i Jakub byli zatem obiektami kpin i szyderstw ze strony swoich współczesnych, a mimo to obaj otworzyli nowy rozdział w historii swoich kultur. Jakub dał początek i nazwę narodowi Izrael, z którym utożsamił się nie kto inny jak sam Jahwe, natomiast Tales, przełamując mityczny obraz świata Greków dał początek kulturze opartej na zaufaniu do rozumu. Wprawdzie Jakub nie należał do najtęższych głów wybranego narodu, ale podobnie jak Tales, mimo przeszkód i szyderstw świetnie radził sobie w życiu. Jak przekazuje Stary Testament[,] Jakub od samego początku żył w cieniu swojego brata bliźniaka Ezawa, którego umiłował ojciec Izaak. W porównaniu z bratem musiał wydawać się nieudacznikiem i niezgułą podporządkowanym nadopiekuńczej matce. Już samo imię, które dosłownie oznacza „trzymający się za pietę” antycypowało upokarzającą relację do Ezawa, który był powszechnie podziwiany, mimo że nie dbał o majątek i status społeczny, o czym świadczy choćby to, że za miskę soczewicy odstąpił Jakubowi swój przywilej pierworództwa. Jakub mimo swoich ułomności wykazywał się dużym sprytem i iście szelmowską przebiegłością - znana jest historia, kiedy to wraz z matką oszukał umierającego, ślepego Izaaka, od którego uzyskał błogosławieństwo na łożu śmierci. Jak podsumowuje żywot słynnego patriarchy Paul Johnson:

${ }^{17}$ D. Zucker, Isaac: a life of bitter laughter, „Jewish Bible Quarterly”, Apr-Jun 2012, vol. 40, s. 105. 
Jakub zupełnie nie przypominał swego dziada, Abrahama. Obłudnik, makiawelik, raczej strateg niż wojownik, polityk, manipulator, a przy tym nauczyciel i wizjoner - Jakub radził sobie w życiu znakomicie i stał się człowiekiem o wiele potężniejszym i zamożniejszym niż Abraham czy Izaak ${ }^{18}$.

Żyjący bez mała tysiąc lat później Tales wykazywał zdecydowanie bardziej korzystny profil biograficzny: urodzony w rodzinie należącej do ówczesnej arystokracji jońskiej, nie przeżywał - z tego, co nam wiadomo - poważnych kryzysów tożsamościowych, a jego relacje z rodzeństwem prawdopodobnie nie rodziły jakichś przełomowych konfliktów. Mimo to, właśnie przez swoją pasję do bezinteresownej kontemplacji natury narażał się na kpiny ze strony swojego otoczenia. W oczach tłumu mógł uchodzić za nieudacznika, a uprawiane przez niego dociekania za synonim godnego potępienia próżniactwa. Oczywiście nie ma prostej symetrii między losami Talesa i Jakuba, tym co pozwala nam przeprowadzić taką nieco forsowną analogię jest osobliwe połączenie stygmatu śmieszności z wysoką rangą, jaką obydwaj osiągnęli $\mathrm{w}$ oczach potomnych. $\mathrm{Z}$ jednej strony mielibyśmy zatem pogardliwy śmiech zbiorowości, z drugiej zaś strony, akt założycielski nowej formacji kulturowej, którego dokonuje wyjątkowa, choć początkowo niedoceniana jednostka. Śmiech broni tutaj racji mitu, który reprezentuje interesy nagiego życia ${ }^{19}$. Mit oswaja pulsujący w rytmie wiecznego powtórzenia żywioł ślepego zoe, przykrywa go niejako ornamentem wyobrażeń, które nadają sens egzystencji pochłoniętej bez reszty walką o przetrwanie. Nie chodzi tutaj jedynie o apolliński pozór, o usypiającą zasłonę maji, która pozwala człowiekowi przeżyć w obojętnym wobec niego świecie, lecz przede wszystkim o element przymusu, owej przemożnej i nieodgadnionej mocy Ananke, mitycznego losu, który niszczy lub skazuje na śmieszność wszystko to, co chce przekroczyć wyzna-

${ }^{18}$ P. Johnson, Historia Żydów, tłum. M. Godyń, M. Wójcik, A. Nelicki, Kraków 2000, s. 15.

${ }^{19}$ Nawiązuję tutaj do pojęcia mitu zaproponowanego przez Maxa Horkheimera i Theodora Adorno w Dialektyce oświecenia (T. W. Adorno, M. Horkheimer, Dialektyka oświecenia, tłum. M. Łukasiewicz, Warszawa 1994, s. 19-59). W najszerszym znaczeniu mit stanowi dla nich system wierzeń, który tworzy wizję świata uwikłaną w figurę wiecznego powrotu, to znaczy, ogranicza horyzont ludzkiego doświadczenia do zaspokajania niezbędnych konieczności życiowych. O greckim pojęciu zoe, które oznacza dziedzinę życia podporządkowanego biologicznemu przymusowi przetrwania pisze między innymi Hannah Arendt [w:] tenże, Kondycja ludzka, tłum. A. Łagodzka, Warszawa 2000, s. 106-112. W tym kontekście przyjmuję, że mit oznacza regresywny aspekt kultury, który wyraża się w tendencji do reprodukowania utrwalonych sposobów przeżywania i kształtowania rzeczywistości społecznej. Mit zamykałby zatem perspektywę rozwoju kulturowego, hamowałby innowacyjność i dążenie do przekroczenia dotychczasowego stanu ludzkiej samowiedzy. 
czone przez niego granice. Śmiech byłby tu jednym z narzędzi wykluczania tego, co zagraża stabilności mitycznie oswojonej egzystencji wspólnoty. Tales i Jakub, każdy na swój sposób przełamują zaklęty krąg życia i zabezpieczającą go mityczną przesłonę. Tales jakby niechcący, podobnie zresztą jak uciekający ze strachu przed bratem Jakub, inauguruje przełom w postawie wobec życia i mitu. Dzięki Jakubowi zbiorowisko nomadów trawiących życie na walce o przetrwanie staje się nagle Izraelem, narodem wybranym, którego dzieje zyskują uniwersalny sens. Z kolei Tales jako pierwszy kieruje ludzką myśl ku ostatecznej zasadzie, która rządzi całym bytem. Ta myśl, jakby powiedział Platon, odwróciła się od natarczywości ciemnego zmysłowego impulsu i odważyła się - nawet jeśli tylko po omacku - szukać prawdy w transcendencji przekraczającej granice czysto empirycznego świata. Po jednej stronie w szeregu ustawia się zatem życie, mit i śmiech, po drugiej: nadzieja na przekroczenie mitycznej, poziomej egzystencji - nadzieja na ruch wertykalny, który już tutaj na Ziemi pozwoli zasmakować czystości życia nieziemskiego.

Anegdota o Talesie ukazuje zatem konflikt między interesami życia a mocą bezinteresowności. Wzrok skierowany ku niebu, oddalony od życiowych potrzeb zadaje kłam wszechwładzy mitu, dlatego jakby w tajemnej zmowie żywioły natury łączą się, żeby upokorzyć pysznego filozofa i strącają go do studni - śmiesznego piekła filozofów. W połowie drogi między Talesem szukającym materialnej prazasady kosmosu a Platonem, który odsłania jego idealną strukturę stoi Sokrates, który chce znaleźć prawdę na Ziemi, w empirycznym żywiole dialogu. Wydaje się, że dla Sokratesa z wczesnych dialogów, ale też z Chmur zwierciadło wody w studni, do której wpada filozof było swoistym lustrem samopoznania. Jeśli tak, to upadek Talesa oznaczałby, że utracił on możliwość poznania samego siebie w studziennym (codziennym) zwierciadle (życia) i na chwilę „zanurzył” się w tym, wobec czego odczuwał wzniosłą obojętność. Słuszna czy nie, taka interpretacja nie spotkałaby się z życzliwą akceptacją Platona. Przyjrzyjmy się zatem bliżej, jak rozwija on koncepcję śmiechu w swoich dialogach.

\section{Platońska koncepcja gelos}

Wątek geloiastyczny pojawia się u Platona w 3 księdze Państwa i w Filebie. Struktura idealnego ustroju odzwierciedla, jak wiemy, mikrokosmos trójdzielnej duszy. Filozof kładzie nacisk na roztropność, sophrosyne - harmonijne współgranie skonfliktowanych części duszy pod przewodnictwem rozumu. To kryterium samoopanowania dotyczy również sztuk, które mają 
ogromny wpływ na życie zbiorowości i psychikę indywiduum. Platon obawia się zgubnego wpływu poezji i muzyki na dusze strażników. Sztuka, która wyzwala silne emocje, zaraża afektami, przyczynia się tym samym do zagubienia wewnętrznej równowagi, dlatego filozof zaleca ocenzurować utwory bądź ich fragmenty, które zawierają w sobie tego rodzaju niebezpieczny potencjał.

Te i wszystkie podobne miejsca będziemy skreślali i poprosimy Homera i innych poetów, żeby się na nas o to nie gniewali, bo to nie dlatego, żeby one nie były poetyczne i niemiłe szerokim kołom do słuchania, ale im bardziej są poetyczne, tym mniej się nadają do słuchania dla dzieci i ludzi dojrzałych, którzy powinni być wolni i więcej się niewoli bać niżeli śmierci ${ }^{20}$.

Co ciekawe do najniebezpieczniejszych afektów filozof zalicza śmiech:

Ale śmiechu też nie powinni kochać nade wszystko. Bo jeżeli się ktoś zanosi gwałtownym śmiechem, to również prowadzi do gwałtownych przemian wewnętrznych. [...] Zatem także, jeśliby ktoś w poezji dawał ludzi wybitnych a zanoszących się śmiechem, nie trzeba tego przyjmować. A jeszcze mniej: bogów $w^{21}$.

Z zacytowanego tutaj, dość lakonicznego fragmentu dowiadujemy się niewiele. Platon wyraża niewątpliwie bardzo nieprzychylne stanowisko wobec śmiechu, który prowadzi do wewnętrznej przemiany, czyli utraty równowagi, kontroli nad wzburzoną emocjami duszą. Jako szczególnie niebezpieczny wskazuje homerycki śmiech bogów, przytaczając końcowy fragment pierwszej księgi Iliady: „Śmiech tedy niezgaszony szczęśliwych bogów ogarnął. Kiedy widzieli Hefajsta, jak chodzi, jak sapie po domu"22. Platon ma tu więc na myśli asbetos gelos - nieugaszony śmiech bogów. Pod koniec pierwszej księgi Iliady Hera zaczyna podejrzewać swojego męża Zeusa o zdradę z Tetydą i kiedy głośno wypowiada swój zarzut, Zeus wpada w furię. W tym momencie do akcji wkracza ich syn Hefajstos, który próbuje złagodzić konflikt i opowiada matce swoją historię, kiedy to rozgniewany ojciec wyrzucił go z Olimpu i w rezultacie został kaleką. Jego opowieść bawi i uspakaja matkę. Ta skądinąd zaskakująca dla nas reakcja Hery świadczy o tonizującym, rozładowującym silne afekty oddziaływaniu śmiechu. Jednak Platona interesuje inny rodzaj gelos. Otóż okaleczony Hefajstos przejmuje rolę nadwornego klauna i podczaszego, który kulejąc przemierza olimpijski pałac i rozdaje ambrozję rozbawionym bogom. Nieugaszony śmiech Olimpijczyków wywołuje

\footnotetext{
${ }^{20}$ Platon, Państwo, tłum. W. Witwicki, Kęty 2003, s. 82 (387 B).

21 Tamże, s. 85 (388 E).

${ }^{22}$ Ustęp cytowany za tłumaczeniem Witwickiego [w:] Platon, Państwo..., s. 85.
} 
tutaj zdegradowany, oszpecony syn Zeusa, który chcąc nie chcąc zmuszony jest pełnić funkcję poddanego. Platon miał na uwadze również inną komiczną sytuację, ponownie z Hefajstosem w roli głównej.

W ósmej Pieśni Odysei Hefajstos dowiaduje się od Heliosa o zdradzie swojej małżonki Afrodyty z Aresem i postanawia zastawić na nich pułapkę w postaci niewidocznej sieci zawieszonej nad łożem. Gdy oboje wpadają w sidła, pojawia się Hefajstos i wzburzony zaprasza do siebie jako świadków zdrady pozostałych bogów. Na to zawołanie przybywają wyłącznie męscy bogowie i stroją sobie z nieszczęśnika mało wyszukane, wulgarne żarty, atmosfera gęstnieje i nagle wybucha homerycki asbestos gelos: „A więc stanęli we drzwiach bogi, dawce doli/ I śmiech ogromny napadł niebian tam zebranych, Gdy ich sztuką Hefajsta widzą powiązanych"23. Pogardliwy śmiech wydaje się nie mieć żadnych granic, podsyca go dodatkowo Apollon, który zapytuje Hermesa, czy chciałby znaleźć się w podobnej sytuacji. Hermes rozpala voyerystyczną uciechę Olimpijczyków, wyznając, że zgodziłby się i na gęstsze pęta, żeby tylko mieć okazję skorzystać z uroków niewiernej Afrodyty:

Bodajby tak się stało, mój celny łuczniku! Niechby trzykroć mnie gęstsze pęta omotały, Niechby bogów i bogiń zbiegł się Olimp cały na ten widok, to jeszcze spałbym przy tej złotej! To rzekł, a w gronie bogów wszczęły się chychoty ${ }^{24}$.

Platon potępia tego rodzaju śmiech nie z powodu jego obsceniczności, ani dlatego, że oburza go skandaliczne potraktowanie Hefajstosa. W kontekście wywodów trzeciej księgi Państwa wyraźnie widać, że zło homeryckiego asbestos gelos tkwi w tym, że bogowie wyśmiewają równego sobie, podważając $\mathrm{w}$ ten sposób fundamenty olimpijskiego ładu, a co gorsze: dodatkowo z rozkoszą pławią się w tym nieposkromionym, zgoła nieboskim rechocie. Pod względem etycznym najważniejsze dla Platona nie jest zatem to, co ktoś czyni, lecz to, czy ma on świadomość tego, co czyni, innymi słowy, czy jest panem swojego działania, czy też nie. Tę kwestię szerzej dyskutuje w Hippiaszu mniejszym, gdzie Sokrates porównuje Odyseusza i Achillesa i za zwycięzcę uznaje właśnie Odyseusza, ponieważ potrafił on z dużym wyprzedzeniem zaplanować swoje oszustwa i przeprowadzić je z chłodną rozwagą ${ }^{25}$. Wzorcem

\footnotetext{
${ }^{23}$ Homer, Odyseja, tłum. L. Siemieński, Gdańsk 2000, s. 84.

${ }^{24}$ Tamże, s. 85.

25 „Ci, którzy szkodzą ludziom i krzywdzą ich, i oszukują, i uchybiają prawu rozmyślnie, a nie mimo woli, ci mi się wydają lepsi niż ci, co mimo woli. Niekiedy znowu wydaje mi się wprost przeciwnie; więc błąkam się na tym punkcie; oczywista dlatego, że nie mam wiedzy. Ale teraz, w tej chwili, jakby mnie coś napadło i wydają mi się rozmyślni przestępcy lepsi
} 
dla Platona wydaje się tutaj sam Sokrates, który irytował swoich rozmówców pytaniem, czy rzeczywiście mają świadomość tego, o czym mówią. Przytoczne przykłady homeryckiego śmiechu nie wyczerpują oczywiście całego spektrum jego wariantów, ale ponieważ Platon skupia się właśnie na nich, możemy przyjąć, że prawdopodobnie stanowiły one dla niego paradygmatyczną formę śmiechu jako takiego.

Jaka jest wspólna nić łącząca homerycki asbestos gelos z drwiną trackiej służącej i śmiechem wskazanym w Teajtecie? Odpowiedź jest prosta. Wszystkie te przypadki łączy asymetria geloiastycznej sytuacji. Zawsze istnieje zatem dominujący podmiot śmiechu oraz jego ofiara: szyderczy bogowie i bezbronny Hefajstos, kpiąca służąca i rozkojarzony Tales, zadowolony z siebie rzutki polites i oderwany od świata filozof, albo, z drugiej strony: dociekliwy mędrzec i powierzchowny sofista. W każdym przypadku mamy do czynienia ze śmiechem $z$ pozycji władzy, adresowanym konkretnie ad personam, a do tego podszytym wyraźną złośliwością, jeśli nie agresją, a tym samym ze śmiechem szyderczym, bezlitosnym i pełnym niepohamowanej radości z wyrządzanej komuś krzywdy. Śmiech dominacji powoduje, że niższa pozycja osoby wyśmiewanej obniża się jeszcze bardziej, wzrasta jej upokorzenie i bezbronność. Co ciekawe, takie ujęcie śmiechu będzie przewijało się niemal przez całą filozofię, znajdziemy je u Augustyna, Hobbesa, Bergsona, Baudelaire’a czy Freuda. Uwypuklony przez Platona śmiech jest śmiechem stadnym, zaraźliwym, wybuchającym nagle jak płomień, który zasilany paliwem ludzkich emocji wciąż od nowa rozpala się i nie daje się ugasić. Gdy przyjrzymy się nieco bliżej przykładom tego śmiechu, definiująca go asymetria okazuje się pozorna, ponieważ w istocie nawet mocarni bogowie stają się ofiarami geloiastycznego impulsu, nie są $\mathrm{w}$ stanie powstrzymać się przed jego nieodpartym, obezwładniającym impetem. Śmiejąc się niemal kompulsywnie obnażają swoją animalną naturę, wulgarność, brak opanowania. Widać to jeszcze wyraźniej, gdy uświadomimy sobie, że nie wszyscy mieszkańcy Olimpu tak reagują. Obsceniczną sceną rozkoszują się wyłącznie męscy bogowie, gdyż „z bogiń żadna nie przyszła - wstyd im tej swawoli” ${ }^{26}$. Do zbiorowego linczu nie przyłącza się również Władca Mórz: „Posejdon się nie śmiał, on prośbą szturmował Hefajsta, by z tych więzów Aresa rozkował”27. Zaraźliwy

pod jakimś względem od mimowolnych." - Platon, Hippiasz mniejszy, [w:] tenże, Dialogi, t. 1, tłum. W. Witwicki, Kęty 1999, s. 144 (372 D).

${ }^{26}$ Homer, Odyseja..., s. 84.

${ }^{27}$ Tamże, s. 85. 
risus ogarnia zatem tych, którzy powiązani są ze sobą łańcuchem wspólnych impulsów, wyobrażeń i emocjonalnych zakłóceń. Zły to zaiste przykład dla przyszłych mieszkańców idealnego państwa.

Przyjrzyjmy się jeszcze ofiarom homeryckiego asbestos gelos: Aresowi, Afrodycie i koniec końców Hefajstosowi. Ares i Afrodyta wpadli w pułapkę zastawioną przez trzecią osobę, ponieważ byli lekkomyślni i na tyle zaślepieni żądzą, że całkowicie zatracili zdolność do oceny swojego postępowania, jak i do przewidywania jego możliwych konsekwencji. Okryli się śmiesznością z głupoty, paląca drwina jest dla nich czymś w rodzaju komicznej kary. Natomiast Hefajstos bez żadnego pośrednictwa sam wmanewrował się w komiczną pułapkę. Tutaj tkwi powód, dla którego Platon tę właśnie scenę wybrał dla zilustrowania istoty komizmu. Hefajstos jest dla niego idealnym przykładem komicznej postaci, która nie pomna groteskowości własnej sytuacji próbuje zrealizować pozornie racjonalny, ale $\mathrm{w}$ istocie małostkowy cel - w przypływie zawiści, zmieszanej z goryczą, wściekłością i skąpstwem żąda on mianowicie, by ojciec Afrodyty zwrócił mu za niewierną żonę pieniądze. Takie kłębowisko sprzecznych emocji bardzo niepokoi Platona i stanie się przedmiotem jego analiz w Filebie.

W dialogu tym pojawia się dyskusja na temat natury przyjemności i przykrości, a ściślej osobliwej ambiwalencji uczuć łączących w sobie obydwa przeciwstawne doznania. Przykrość doznajemy wówczas, gdy postrzegamy niezgodne z naturą stany, kiedy natomiast stany te powracają do pierwotnej równowagi zgodnej z naturą, odczuwamy przyjemność. Przyjemność i przykrość mogą pojawić się w formie czystej i mieszanej, jako takie ograniczają istotny dla równowagi duszy, całkowicie wolny od emocji stan rozwagi czy roztropności (phronesis), który gwarantuje ludziom „może najbardziej boski żywot ze wszystkich" ${ }^{28}$, chociaż i nieśmiertelni mogą czasem utracić rozwagę, jak pokazał przykład z Homera. Tym bardziej właśnie śmiertelny człowiek, który ignoruje maksymę „niczego nad miarę” naraża się na destrukcyjne oddziaływanie intensywnych, ambiwalentnych sił popędowych, które strącają go w otchłań szaleństwa. „A głupców i rozpustników gwałtowna rozkosz do szałów doprowadza [...] w pewnym upodleniu duszy i ciała, a nie, w dzielności największe rozkosze się lęgną i największe cierpienia"29. Maksyma roztropności „niczego nad miarę” funkcjonuje u Platona jako zasada hamująca czy neutralizująca rozchwiane, jednostronnie napięte stany emocjonalne.

\footnotetext{
${ }^{28}$ Platon, Fileb, tłum. W. Witwicki, Kęty 2002, s. 38 (33 B).

${ }^{29}$ Tamże, s. 59 (45 E).
} 
W istocie każde uczucie, jakiego doznaje człowiek znajdujący się w stanie rozwagi, stanowi zbalansowany układ doznań przyjemnych i przykrych. $\mathrm{W}$ większości pozostałych niezrównoważonych stanów mamy do czynienia z układami mieszanymi, w których raz dominuje rozkosz, innym razem ból. Przykładem jest rozkosz seksualna, zawsze zaprawiona elementem cierpienia. Jak powiada Sokrates: „I potem on sam o sobie, a drugi o nim mówi, że w takich rozkoszach jakby umierał." ${ }^{30}$ Wewnętrzna popędowa dynamika duszy nie znosi próżni. Emocjonalne wyciszenie budzi niepokój, który wyzwala potrzebę emocjonalnego poruszenia, zazwyczaj, w niepatologicznych przypadkach - potrzebę rozkoszy - "Że kiedy człowiek ma pustkę w sobie, wtedy napełnienia pożąda i cieszy się nadzieją, a gdy go pustka wewnętrzna najdzie, wtedy cierpi." ${ }^{31}$ Do najważniejszych kompleksów ambiwalentnych odczuć należy gniew, strach, tęsknota, żal, miłość, zazdrość i zawiść. Rozkosz i cierpienie funkcjonują tutaj jako rodzaj meta-emocji, ponieważ to one stanowią kryterium, według którego oceniamy pozostałe uczucia. Podobnie jak tragedia również komedia wykorzystuje tego rodzaju napięcie między przyjemnością i przykrością. Co ciekawe, platoński Sokrates wyprowadza naturę tego, co śmieszne z zawiści, jak tłumaczy grecki termin phtonos Witwicki. Zatrzymajmy sie nieco dłużej przy tym pojęciu, wokół którego rozgorzała dyskusja wywołana przez Gadamera.

Gadamer odwołując się do Heidegerrowskiego pojęcia troski (die Sorge), zaproponował, żeby oddać greckie phtonos za pomocą wyrażenia Konkurrenzsorge, czyli troski o konkurencję. Filozof wskazuje, że centralnym aspektem zawiści jest radość płynąca z czyjegoś nieszczęścia (Schadenfreude). Teza ta wydaje się w pełni uzasadniona, ponieważ $\mathrm{w}$ analizowanym fragmencie Fileba wskazuje na to sam Sokrates. Oddajmy głos Gadamerowi:

A podstawą takiego tłumaczenia nie jest po prostu to, że «zazwyczaj» jesteśmy zawistni (wobec szczęścia przyjaciela) a gdy doznaje on nieszczęścia, czerpiemy z tego radość, lecz nasza radość płynąca z czyjegoś nieszczęścia sama jest formą przejawiania się tej samej podstawowej troski o konkurencję, która wyraża się w obliczu szczęścia przyjaciela jako zawiść [...] U Platona owa struktura troski o konkurencję, która funduje radość z nieszczęścia i zawiść, nie znajduje jednak żadnego pozytywnego oddźwięku, ale nie ma wątpliwości, że ma on na myśli ten podstawowy afekt (który jedynie a potiori określił jako phtonos), gdy utwierdza w samej Schadenfreude domieszkę cier-

\footnotetext{
${ }^{30}$ Tamże, s. 61 (47 B).

${ }^{31}$ Tamże, s. 61 (47 C).
} 
pienia [...] phtonos można zatem określić w najszerszym znaczeniu następująco: $\mathrm{w}$ byciu ku innemu spoglądanie na siebie samego i określanie swojego własnego bytu ku niemu z tej zatroskanej perspektywy ${ }^{32}$.

Troska o konkurencję jest zatem nie tyle subiektywnym uczuciem, ale rodzajem emocjonalnej sceny między dwiema osobami. W scenie tej kluczowym, formującym relację Ja-Ty impulsem okazuje się być czujne, zawistnie nieufne spojrzenie na potencjalnego rywala. W kontekście śmiechu, który nas tutaj zajmuje, możemy uzupełnić uwagi Gadamera o jeden istotny szczegół. Jeśli uznamy homerycki asbestos gelos za paradygmatyczny przykład śmiechu u Platona, wówczas będziemy musieli dodać, że phtonos czy troska o konkurencję zakłada relację góra - dół w przeciwieństwie do zazdrości opartej na przeciwnej relacji dół-góra. Wyśmiewający Hefajstosa bogowie zajmują bowiem wyższą od niego pozycję, nie zazdroszczą mu przecież niczego, wręcz przeciwnie ich radość płynie z wyraźnego odczucia jego upokorzenia, upadku. Ta niejako odgórna zawiść ociera się o agresję, a niekiedy prowadzi do zachowań sadystycznych jak w przypadku Prometeusza, czy - wskazując przykład biblijny - Hioba. Kolejną różnicą między zazdrością a phtonos jest to, że osoba zazdrosna czuje się we własnym mniemaniu upokorzona, a przez to zachowuje się biernie, bezsilnie - być może to odczucie zmobilizuje ją w przyszłości do jakiegoś działania, ale aktualnie paraliżuje ją i zamyka $\mathrm{w}$ stanie pasywności, podczas gdy zawistne phtonos niemal automatycznie popycha do aktywności, do potęgowania upokorzenia poprzez słowne docinki, różnego rodzaju złośliwe intrygi, oszczerstwa, obelgi i magię pogardliwego spojrzenia.

Platon łączy zatem śmiech z phtonos i przechodzi do definicji obiektu śmiechu, czyli tego, co jest śmieszne, a właściwie tego, co powoduje, że ktoś jest śmieszny. Na początku stwierdza, że śmiech wywołuje wada, a ściślej wada wynikająca z niewiedzy o sobie. Niewiedza ta może opierać się na fałszywej, zawyżonej ocenie własnej wielkości, mocy, piękna, umiejętności, a wreszcie mądrości. Przeceniająca swoją wartość niewiedza również łączy się $\mathrm{z}$ afektem phtonos, ale jakby złagodzonym. Platon pisze w tym przypadku o dziecinnej, głupiej zawiści (paidikos phtonos). Śmiech platoński przybiera zatem, jeśli właściwie rozumiemy ten fragment, dualną strukturę. Z jednej strony mamy dziecinnie zawistny, cierpiący na manię wielkości podmiot, któremu wydaje się, że realizuje swój zamiar - przykładem jest Hefajstos,

${ }^{32}$ H. G. Gadamer, Platos dialektische Ethik (1931), [w:] tenże, Gesammelte Werke, t. 5, s. 154. Cytuję za: L. Prütting, Homo ridens..., s. 116. 
który łudzi się, że jest sprytny i odzyska pieniądze zainwestowane w małżonkę, z drugiej zaś strony, podmiot, który nieoczekiwanie staje się świadkiem obnażenia czyjejś autoiluzji, albo sam ją dementuje - przykładem są oczywiście Olimpijczycy. Pojęcie zawiści rozumiane w potocznym znaczeniu może zaciemnić rozumienie omawianego fragmentu tekstu, pamiętajmy więc, że zgodnie z Gadamerem phtonos należy interpretować jako rodzaj zatroskania w pewnej konkurencji, rywalizacji. Hefajstos dziecinnie, to znaczy w całkowitej niewiedzy, troszczy się o to, żeby wygrać z góry skazaną na przegraną rywalizację z Aresem, ale też oczywiście z Afrodytą, która go skrzywdziła. Czuje się upokorzony, a to wywołuje w nim ogromne napięcie, wzmacnia wiarę w sukces zemsty. Im silniej w to wierzy, z tym większej wysokości upada, tym śmieszniejszy wydaje się bogom, tym wyżej czują się oni w swoich własnych oczach. Używając metaforyki Baudelaire’a, możemy powiedzieć, że dynamikę, jaka zachodzi między śmiesznością a śmiechem inicjuje moment strącenia do piekieł śmiesznej ofiary a kończy - błazeńskie wniebowzięcie śmiejącego się szydercy ${ }^{33}$. Bogowie zostają dosłownie porwani przez śmiech, ale w ten sposób tracą samoopanowanie, sami stają się dziecinnie zawistni.

Dla Platona kluczowa w tej sytuacji jest asymetria między słabością ofiary a mocą śmiejącego się. Równowaga sił dławi bowiem śmieszność i rozkręca spiralę wzajemnej agresji.

Jedni z nich są przy tym słabi i nie potrafią się pomścić na tym, który by ich wyśmiał. Jeżeli powiesz, że to są ludzie śmieszni, powiesz prawdę. Drudzy potrafią się mścić i są mocni. Jeżeli o tych powiesz, że straszni, znienawidzeni, najsłuszniej sobie zdasz z nich sprawę. Niewiedza ludzi potężnych budzi nienawiść i pogardę, bo przynosi szkodę także ich bliźnim - wszelkie jej odwzorowania tak samo - niewiedza słabych budzi w nas śmiech i jest śmieszna $\mathrm{z}$ natury ${ }^{34}$.

Śmiech okazuje się w istocie mieszaniną rozkoszy i przykrości, którą wnosi do niego podszyty agresją phtonos.

Uznajmy to określenie za ostatnie słowo Platona w kwestii śmiechu, gdyż tyle tylko znajdujemy na ten temat w zachowanych tekstach. Śmiech, a ściślej wywołujące go utwory komiczne lub satyryczne ustępy, jak epizod z Hefajstosem, zostaje potępiony i nie znajduje dla siebie miejsca w idealnym państwie. Głównym grzechem tej mieszaniny rozkoszy i cierpienia jest utrata

${ }^{33}$ Ch. Baudelaire, O istocie śmiechu oraz komizmie, tłum. J. Guze, [w:] B. Dziemidok, O komizmie. Od Arystotelesa do dzisiaj, Gdańsk 2011, s. 318-325.

${ }^{34}$ Platon, Fileb..., s. 64 (49 C). 
siebie, utrata roztropności, która wystawia człowieka na rozliczne niebezpieczeństwa.

$\mathrm{Na}$ koniec pozostaje nam jeszcze pytanie, jak ma się do tej definicji śmiechu Sokratejska ironia? Ironia, czyli dosłownie samo-umniejszenie wydaje się przeciwieństwem samozapomnienia, nieuzasadnionego samo-wywyższenia się, które tak zdecydowanie potępia Platon. Sama struktura sokratycznego dialogu przypomina asymetryczną relację między Olimpijczykami a Hefajstosem. Również tutaj mamy do czynienia ze swoistym pojedynkiem o dominacje - z jednej strony widzimy dziecinnie zawistną ofiarę, przekonaną o swojej wyższości, z drugiej zaś strony - silniejszego pod względem retorycznego kunsztu filozofa błazna. Istotna różnica polega jednak na tym, że Sokrates nie jest bynajmniej powodowany zawistnym phtonos, a pragnieniem wiedzy wypływającym z ironicznej maksymy „wiem, że nic nie wiem”. Jeśli nawet uwierzymy, że filozof faktycznie ma nadzieję na maieutyczne narodziny wiedzy w prowadzonym przez siebie dialogu (Platon wskazuje kilka przykładów udanego położnictwa), to nie powinniśmy oszukiwać się, myśląc, że zachowuje on w dyspucie niewinną postawę wobec rozmówcy. Elenktyczne zapytywanie prowadzi w większości przypadków do obnażenia niewiedzy pyszałkowatych, choć cenionych mieszkańców polis i w ten sposób oczyszcza przynajmniej częściowo chaos mętnych, sprzecznych ze sobą opinii, które tworzą ateńską doxa. Czytając platońskie dialogi trudno zignorować pewną domieszkę inkwizycyjnej dociekliwości, czy zwykłej złośliwości ze strony Sokratesa. Im bardziej filozof-ironista umniejsza siebie, tym bardziej wywyższa pozycję swojej ofiary. Beztrosko przyjmuje rzucane od niechcenia odpowiedzi za dobrą monetę i podstępnie narzuca własne reguły gry. To wertykalne napięcie w rywalizacji o prawdę kończy się często nagłym rozładowaniem, które strąca ofiarę w bezlitosne otchłanie śmieszności. Sokrates z wczesnych dialogów przejawia ewidentnie cechy notorycznego uwodziciela, bałamuta i intryganta, którego rozpoznajemy w komediach z całego świata. Jego ironiczne zabiegi prowadzą zazwyczaj do tego, że potencjalna ofiara sama ochoczo buduje sidła, w które niechybnie wpadnie. Oczywiście bez trudu dostrzegamy w nim również figurę błazna, który uchyla się przed panującym status quo i asekurowany przyznanym mu immunitetem odsłania w oparach śmiechu prawdę ukrytą przed innymi.

Co na to Platon? Dlaczego w swoich analizach śmiechu w ogóle nie uwzględnia Sokratesa? Czy to oznacza, że z uwagi na szacunek dla nauczyciela aprobuje jego ironiczną metodę i nie chce jej oceniać? Czy też postrzega ją tylko jako etap wstępny do własnej filozofii? Nasuwające się pytania dotyczą 
różnych problemów. W interesującym nas tutaj kontekście najważniejsze jest pytanie o nieobecność ironii w platońskiej koncepcji śmiechu. Wskazówkę, która może ułatwić nam odpowiedź, znajdziemy w Teajtecie, wróćmy zatem jeszcze raz do anegdoty o Talesie. Choć nie jest ona do końca jasna, wszystko wskazuje na to, że Platon trzyma stronę wpatrzonego w niebo filozofa, ponieważ uprawia on przecież theoria, czystą, bezinteresowną kontemplację kosmosu, zapoczątkowując tym samym platoński ideał poznania. Jeśli zgodzimy się na taką tezę, to będziemy zmuszeni uznać, że Sokrates, przynajmniej ten $\mathrm{z}$ wczesnych dialogów, nie spełnia tak wysoko postawionego ideału. Noetyczny wgląd w idealną strukturę wszechświata wykracza nie tylko poza potoczny język, ale też poza wszelką, najczystszą nawet wiedzę pojęciową. Powtórzmy, uchwycenie prawdy, która odsłania się przed okiem duszy filozofa, nie pozostawia żadnego miejsca na śmiech i śmieszność. Drwiny mieszkańców jaskini z potykającego się mędrca świadczą jedynie o tym, że wciąż grzęzną oni w błocie zmysłowego poznania. Z kolei ironia to najwyżej wstępny krok na długiej i krętej drodze duszy wznoszącej się w pionowych obrotach ku prawdziwie bytującemu bytowi. Mówiąc krótko, śmiejący się Sokrates z wczesnych dialogów nie pasuje do późnej filozofii Platona, która wyraźnie dociera do prawdy samej, mimo że pomna jest wszystkich powikłań i trudności związanych z cielesną kondycją mówiącej istoty, która aspiruje tak wysoko. Autor Państwa stawia krok dalej niż jego nauczyciel, krok poza granice tego, co empiryczne. Ostatecznie postać Sokratesa traci w późnych dialogach swoje żywe kolory i groteskowe nieraz kontury, ulatniając się w słonecznym blasku platońskiego ideału episteme. U końca drogi śmiech staje się zbędny, nikną bowiem powody, które mogłyby go wywołać. Tyle Platon i ukazany przez niego Sokrates. Zastanówmy się teraz nad innym wizerunkiem ironisty, jaki przedstawia Arystofanes w swoich Chmurach. Główne pytanie, które będzie kierować naszymi rozważaniami w kolejnym artykule, dotyczy tego, czy nie jest czasem tak, że w kontekście śmiechu i tylko w tym kontekście, Arystofanes wierniej oddaje postać Sokratesa aniżeli Platon. Nie chodzi nam rzecz jasna o poszukiwanie „autentycznego” Sokratesa, lecz o figurę Sokratesa ironisty, który wychodząc od gorzkiej świadomości swojej absolutnej niewiedzy dąży jednak do prawdy w żywiole dialogu z innymi. 


\section{Bibliografia}

Adorno T. W., Horkheimer M., Dialektyka oświecenia, tłum. M. Łukasiewicz, Warszawa 1994.

Arendt H., Kondycja ludzka, tłum. A. Łagodzka, Warszawa 2000.

Arystoteles, Polityka, [w:] tenże, Dzieła wszystkie, t. 6, tłum L. Piotrowicz, Warszawa 2001.

Baudelaire Ch., O istocie śmiechu oraz komizmie, tłum. J. Guze, [w:] B. Dziemidok, O komizmie. Od Arystotelesa do dzisiaj, Gdańsk 2011.

Bergson H., Śmiech, tłum. S. Cichowicz, Kraków 1977.

Blumenberg H., Der Sturz des Protophilosophen - Zur Komik der reinen Theorie anhand einer Rezeptionsgeschichte der Thales-Anekdote, [w:] Das Komische, (wyd. W. Presendanz, R. Warning), München 1976.

Filostrat Starszy, Obrazy, tłum. R. Popowski, Warszawa 2004.

Homer, Odyseja, tłum. L. Siemieński, Gdańsk 2000.

Johnson P., Historia Żydów, tłum. M. Godyń, M. Wójcik, A. Nelicki, Kraków 2000.

Kant I., Krytyka władzy sądzenia, tłum. J. Gałecki, Warszawa 1986.

Platon, Fileb, tłum. W. Witwicki, Kęty 2002.

Platon, Hippiasz mniejszy, [w:] tenże, Dialogi, t. 1, tłum. W. Witwicki, Kęty 1999.

Platon, Państwo, tłum. W. Witwicki, Kęty 2003.

Platon, Fedon, [w:] Platon, Dialogi, t. 1, tłum. W. Witwicki, Kęty 1999.

Platon, Gorgiasz, [w:] Platon, Dialogi, t. 1, tłum. W. Witwicki, Kęty 1999.

Platon, Protagoras, [w:] Platon, Dialogi, t. 1, tłum. W. Witwicki, Kęty 1999.

Platon, Teajtet, [w:] Platon, Dialogi, t. 2, tłum. W. Witwicki, Kęty 2005.

Plessner H., Śmiech i płacz, tłum. A. Zwolińska, Z. Nerczuk, Kęty 2004.

Prütting L., Homo ridens, t. 1, München 2013.

Pseudo-Hippokrates, O śmiechu Demokryta, tłum. K. Bartol, Gdańsk 2007.

Zucker D., Isaac: a life of bitter laughter, „Jewish Bible Quarterly”, Apr-Jun 2012, vol. 40 .

\section{Abstract \\ Considerations Around the Platonic Conception of Laughter}

The purpose of this article is a critical reconstruction of the Platonic conception of laughter, which is presented primarily in Republic and Philebus. A comic quality calls, in his opinion, to lower emotions, it throws human mind out of balance and undermines the prevailing order of values. The philosopher associates a laughter with the feeling of envy (phtonos), which comes down to the joy of humiliating of someone weaker. The comic envy - as opposed to passive jealousy - almost automatically leads 
to the activity, to the enhancement of humiliation. Laughter is caused according to Plato by a defect resulting from the ignorance about himself. The key feature of the comic situation is the asymmetry between the victim's weakness and the strength of a laughing person. Plato's concept of laughter turns out to be one-sided, when we compare it with „laughter of Democritus" which serves as a therapeutic and catharctic means. Laughter is here a clear signal that initiates the critical reflection on himself and gives impetus to a change of attitude towards the world. In his writings Plato did not include such educational and cognitive aspects of laughter because in his philosophy it becomes a specific antagonist of true knowledge. The negative attitude towards laughter does not go hand in hand with Plato's recognition of Socrates, who used irony as a key element in his method of inquiry leading to truth.

Key words: Plato, Socrates, Homer, Democritus, irony, laughter, comedy 